\title{
Penerapan Perilaku Hidup Bersih dan Sehat Anak Usia Dini di Tengah Pandemi Covid 19
}

\author{
La Ode Anhusadar ${ }^{\circledR}$, Islamiyah ${ }^{2}$ \\ Pendidikan Islam Anak Usia Dini, Institut Agama Islam Negeri Kendari ${ }^{1}$ \\ Keperawatan, Sekolah Tinggi Ilmu Kesehatan, Mandala Waluya Kendari2 \\ DOI: $10.31004 /$ obsesi.v5i1.555
}

\begin{abstract}
Abstrak
Penelitian ini dilakukan dengan tujuan untuk mengetahui pemahaman orang tua terhadap pentingnya penerapan perilaku hidup bersih dan sehat, untuk mengetahui bentuk-bentuk penerapan perilaku hidup bersih dan hidup sehat dan untuk mengetahui penerapan perilaku hidup bersih dan sehat pada anak usia dini. Penelitian ini dilakukan dengan metode penelitian survey deskriptif. Sampel pada penelitian ini adalah orang tua yang memiliki anak yang sedang menempuh jenjang Pendidikan Anak Usia Dini di Kendari yaitu KB Sultan Qaimuddin Kendari dan KB Nurul Maghfirah Kendari. Peneliti menggunakan teknik pengumpulan data berupa wawancara dan angket. Temuan dalam penelitian ini adalahsebanyak $100 \%$ responden orang tua melihat sangat penting penerapan perilaku hidup bersih dan sehat selama pandemic covid 19 ini. Sebanyak 98\% atau 50 responden sudah mengetahui program perilaku hidup bersih dan sehat sedangkan $2 \%$ atau 1 responden belum mengetahui program perilaku hidup bersih dan sehat. Penerapan perilaku hidup bersih dan sehat pada anak usia dini di lingkungan keluarga di tengah pandemi ini sangat baik.
\end{abstract}

Kata kunci: pola asuh; perilaku hidup; bersih dan sehat; anak usia dini

\begin{abstract}
The Purpose of this research is to determine the understanding of parents about the importance of application of clean and healthy living behavior, know how to live application of clean and healthy behavior and to know the application of clean and healthy living behaviors in early children. This research was conducted with a descriptive survey research method. The sample in this study were parents who had children who were pursuing Early Childhood Education in Kendari, namely Sultan Qaimuddin Kendari KB and KB Nurul Maghfirah Kendari. Researchers used data collection techniques such as interviews and questionnaires. The findings in this study are $100 \%$ of respondents who consider the importance of planning a healthy and healthy life during a pandemic covid 19. As many as $98 \%$ or 50 respondents already know the clean and healthy living program $2 \%$ or 1 respondent does not know the clean and healthy living program. The application of clean and healthy living behavior in early childhood in a family environment in the middle of this pandemic is very good.
\end{abstract}

Keywords: parenting, clean and healthy living behaviors, early childhood

Copyright (c) 2020 La Ode Anhusadar, Islamiyah

$\triangle$ Corresponding author: La Ode Anhusadar

Email Address : sadar.wanchines@gmail.com (Kendari, Sulawesi Tenggara, Indonesia)

Received 27 May 2020, Accepted 2 July 2020, Published 9 July 2020 


\section{PENDAHULUAN}

Masuknya virus corana di Indonesia membawa dampak besar terhadap kehidupan masyarakat, mulai dari kehidupan kesehatan, ekonomi, sosial, keagamaan maupun dunia pendidikan. Dampak virus corana dalam dunia pendidikan bisa terlihat pada kebijakan pemerintah pusat hingga daerah memberikan kebijakan untuk meliburkan seluruh lembaga pendidikan dari tingkat Pendidikan Anak Usia Dini (PAUD) sampai perguruan tinggi. Hal ini dilakukan sebagai upaya mencegah meluasnya penularan virus corona. Diharapkan dengan seluruh lembaga pendidikan tidak melaksanakan aktivitas seperti biasanya, hal ini dapat meminimalkan menyebarnya penyakit covid 19 ini. Hal serupa juga sudah dilakukan oleh berbagai negara yang terpapar penyakit covid 19 ini, kebijakan lockdown atau karantina dilakukan sebagai upaya mengurangi interaksi banyak orang yang dapat memberi akses pada penyebaran virus corona. Menurut Hermansyah (2020) sebelum menjadi pandemik, virus ini mulanya terjadi di Kota Wuhan, Provinsi Hubei, Cina pada bulan Desember 2019. Terdapat sebuah laporan yang memberitakan bahwa sedang terjadi wabah pneumonia terkait dengan virus yang disebut sebagai Severe Acute Respiratory Syndrome Coronavirus-2 (SARS-CoV-2). Infeksi dari virus tersebut menjalar dengan cepat hingga ke seluruh daerah di China dan negara-negara lainnya di seluruh dunia pada beberapa minggu berikutnya sedangkan menurut WHO Coronaviruses $(\mathrm{CoV})$ merupakan bagian dari keluarga virus yang menyebabkan penyakit mulai dari flu hingga penyakit yang lebih berat seperti Middle East Respiratory Syndrome (MERS-CoV) and Severe Acute Respiratory Syndrome (SARS-CoV). Penyakit yang disebabkan virus corona, atau dikenal dengan COVID-19, adalah jenis baru yang ditemukan pada tahun 2019 dan belum pernah diidentifikasi menyerang manusia sebelumnya(Laode Anhusadar, 2020).

Belum usainya masa tanggap darurat pandemi Covid-19, membuat masyarakat semakin resah. Tidak terkecuali para orang tua yang mulai gelisah dengan keadaan putraputrinya di rumah. Tidak ada aktifitas di luar rumah, termasuk aktivitas belajar di sekolah. Hal ini merupakan kebijakan pemerintah dalam rangka menangulangi pandemi ini. Kondisi aktifitas pendidikan yang diliburkan ini, membuat proses pembelajaran yang dilakukan di rumah diambil alih oleh orang tua. Orang tua dituntut untuk mampu mengganti peran guru di sekolah, sehingga membuat orang tua harus kreatif dalam mengajarkan anak-anak. Terlebih lagi bila anak masih dalam jenjang PAUD orang tua membutuhkan kreativitas sehingga anak bisa bermain sambal belajar di rumah. Dalam kegiatan bermain sambil belajar merupakan kegiatan yang baik untuk anak. Menurut Hurlock (1993), bermain adalah setiap kegiatan yang dilakukan untuk kesenangan yang ditimbulkan tanpa pertimbangan hasil akhir. Melalui bermain anak akan memiliki berbagai manfaat bagi perkembangan, aspek ini saling menunjang satu sama lain dan tidak dapat dipisahkan. Apabila satu aspek tidak diberikan kesempatan untuk berkembang, maka akan terjadi ketimpangan karena bermain adalah aktivitas yang menyenangkan dan merupakan kebutuhan yang sudah melekat dalam diri anak (La Ode Anhusadar, 2016).

Merubah kebiasaan memanglah sulit, namun momentum ini membuat kita semua melakukan perilaku hidup bersih dan sehat ini. Siapapun tidak akan mau terpapar virus ini. Maka dari itu, semua akan berubah dengan melakukan perilaku hidup bersih dan sehat, dan merubah karakter setiap individu ke arah yang lebih baik. Sehingga nantinya membuat kualitas hidup manusia semakin baik. Anak-anak sedari kecil melakukan dan dibentuk perilaku seperti ini, akan terbawa sampai mereka dewasa nantinya. Pengalaman selama pandemi ini akan membuat mereka terbiasa melakukan perilaku hidup bersih dan sehat di kemudian hari. Banyaknya angka anak usia dini yang belum mendapatkan layanan pendidikan juga dipengaruhi oleh persepsi orangtua terhadap pendidikan anak usia dini (Pratiwi, Widiastuti, \& Rahardjo, 2018). Pola asuh adalah cara orang tua mendidik anak dan membesarkan anak yang dipengaruhi oleh banyak faktor, antara lain faktor budaya, agama, kebiasaan dan kepercayaan, serta kepribadian orang tua (orang tua sendiri atau orang yang mengasuh anak). Pola asuh yang biasa diterapkan antara lain pelindung, penuntut, 
dominan, pemanja, permisif, rejektif, pengkritik, tidak konsisten (Erik Sulistiana, 2013). Pola asuh pelindung membentuk anak menjadi penakut, tidak percaya diri, merasa khawatir, ragu, tidak mandiri, dan bila anak berontak akan melakukan semua larangan orang tua. Pola asuh penuntut bila anak gagal memenuhi tuntutan orang tua anak akan mengalami frustasi diikuti rasa bersalah dan dosa serta bila anak berontak maka akan sengaja menggagalkan diri.

Orang tua bisa menemani anak dalam bermain di rumah sehingga anak bisa mengembangkan kecerdasan majemuk yang anak miliki. Pendidikan keluarga merupakan proses pemberian nilai-nilai positif bagi tumbuh kembangnya anak sebagai fondasi pendidikan selanjutnya. Menurut Al-Gazali dalam Jailani bahwa konsep pendidikan bahwa pendidikan agama harus dimulai sejak usia dini. Sebab, dalam keadaan ini anak siap untuk menerima aqidah-aqidah agama semata-mata atas dasar iman, tanpa meminta dalil untuk menguatkannya, atau menuntut kepastian dan penjelasan. Oleh sebab itu, di dalam mengajarkan agama kepada anak-anak, hendaknya dimulai dengan menghafal kaidahkaidah dan dasar-dasarnya. Setelah itu baru guru menjelaskan maknanya, sehingga mereka memahami, meyakini dan membenarkannya (Giantara, Yanti, Handayani, \& Anis, 2020). Pola asuh orang tua mempengaruhi seberapa baik anak membangun nilai-nilai dan sikapsikap anak yang bisa dikendalikan. Suherman, pakar perkembangan anak telah mengelompokkan pola asuh ke dalam tiga tipe : (1). Pola asuh otoriter adalah pola pengasuhan anak yang bersifat pemaksaan, keras dan kaku di mana orang tua akan membuat berbagai aturan yang harus dipatuhi oleh anak-anaknya tanpa mau tahu perasaan sang anak. Orang tua akan emosi dan marah jika anak melakukan hal yang tidak sesuai dengan yang diinginkan oleh orang tuanya. (2). Pola asuh permisif adalah jenis pola mengasuh anak yang tidak peduli terhadap anak. Jadi apapun yang mau dilakukan anak diperbolehkan seperti tidak sekolah, bandel, melakukan banyak kegiatan maksiat, pergaulan bebas negatif, matrialistis dan sebagainya. (3). Pola asuh demokratis adalah pola asuh orang tua pada anak yang memberi kebebasan pada anak untuk berkreativitas dan mengeksplorasi berbagai hal sesuai dengan kemampuan anak dengan sensor batasan dan pengawasan yang baik dari orang tua (Joni, 2015).

Menurut departemen kesehatan, pendidikan kesehatan anak usia dini dilakukan oleh orang tua harus didasarkan pada prinsip-prinsip berikut: (1). Berorientasi pada kebutuhan pertumbuhan dan perkembangan anak. (2). Kegiatan pembelajaran dilakukan untuk pemenuhan kebutuhan bermain. (3). Merangsang kreativitas dan inovasi dalam hidup bersih dan sehat. Kreatifitas dan inovasi tercermin melalui kegiatan yang membuat anak tertarik dan menyenangkan. (4). Menyediakan lingkungan dan fasilitas sanitasi kesehatan yang mendukung proses belajar. (5). Mengembangkan kecakapan hidup bersih dan sehat. Kecakapan hidup diarahkan untuk membantu anak menjadi mandiri, disiplin, mampu bersosialisasi dan memiliki keterampilan dasar yang berguna bagi kehidupannya kelak. (6). Menggunakan berbagai sumber dan media belajar yang ada di lingkungan sekitar. (7). Dilaksanakan secara bertahap dan berulang-ulang dengan variasi yang cukup dengan mengacu pada prinsip-prinsip pertumbuhan dan perkembangan anak. (8). Rangsangan pendidikan bersifat menyeluruh mencakup semua aspek kesehatan untuk pertumbuhan dan perkembanagan anak. Tugas pendidik adalah memfasilitasi agar semua aspek perkembangan anak dapat berkembang secara optimal (Heny Wulandari, 2014).

Orang tua dituntut untuk bisa menjaga kesehatan anak selama masa pandemic corana ini sehingga anak dalam kondisi yang sehat. Cara yang bisa dilakukan oleh orang tua dalam menjaga kesehatan anak adalah dengan pembiasaan perilaku hidup bersih dan sehat di lingkungan rumah. Pengalaman orang tua dalam mengikuti kegiatan-kegiatan parenting di sekolah sudah harus diterapkan dalam meningkatkan kebutuhan gizi dan kesehatan anak selama masa pendemi corona ini. Tujuan program parenting education dalam kesehatan dan gizi akan diupayakan melalui pengembangan materi yang menurut Direktorat Pembinaan Pendidikan Anak Usia Dini tahun 2012 mencakup 6 (enam) bahasan, yaitu: (1) peningkatan 
gizi, (2) pemeliharaan kesehatan, (3) perawatan, (4) pengasuhan, (5) pendidikan, dan (6) perlindungan. Enam materi di atas akan dijadikan poin dasar dalam kegiatan parenting education (Fitroh \& Oktavianingsih, 2020). Menurut Notoatmojo Beberapa hal yang perlu diajarkan pada anak untuk mengembangkan perilaku sehat, yaitu menjaga kebersihan diri maupun kebersihan lingkungan dan menjauhkan hal-hal yang berbahaya untuk kesehatan. Kebersihan lingkungan adalah kebersihan tempat tinggal, tempat kerja atau bermain, dan sarana umum. Anak dapat diajarkan tentang kebersihan lingkungan ini sejak dini. Kegiatan paling sederhana yang dapat dilakukan anak usia dini adalah meletakkan alas kaki pada tempatnya; menggunakan alas kaki jika hendak keluar rumah; membuang sampah pada tempatnya; meletakkan peralatan makan minum yang kotor pada tempatnya; membersihkan mainan; menutup mulut pada saat batuk dan bersin; menjauhi asap rokok, asap pembakaran sampah, asap kendaraan bermotor; serta buang air besar (BAB) dan buang air kecil (BAK) di toilet. Selain itu orang tua dapat melibatkan anak usia dini dalam kegiatan-kegiatan terkait dengan pemeliharaan kebersihan lingkungan seperti membereskan mainan, menyapu rumah, mengepel rumah, menyapu halaman, dan lain-lain (Apriliana Kuntoro Astuti, 2016)(Apriliana Kuntoro Astuti, 2016)(Apriliana Kuntoro Astuti, 2016)(Apriliana Kuntoro Astuti, 2016)(Apriliana Kuntoro Astuti, 2016)(Apriliana Kuntoro Astuti, 2016)(Apriliana Kuntoro Astuti, 2016)(Apriliana Kuntoro Astuti, 2016)(Apriliana Kuntoro Astuti, 2016)(Apriliana Kuntoro Astuti, 2016)(Apriliana Kuntoro Astuti, 2016)(Apriliana Kuntoro Astuti, 2016)(Apriliana Kuntoro Astuti, 2016)(Apriliana Kuntoro Astuti, 2016)(Apriliana Kuntoro Astuti, 2016)(Apriliana Kuntoro Astuti, 2016)(Apriliana Kuntoro Astuti, 2016).

Pandemi covid 19 ini juga telah merubah kebiasaan masyarakat. Setiap individu di setiap keluarga telah melakukan berbagai upaya dalam ikut serta menanggulangi atau memutus rantai penyebaran pandemi ini. Kebiasaan masyarakat yang paling kentara terlihat yaitu perilaku hidup bersih dan sehat (PHBS). Selama ini perilaku hidup bersih dan sehat tidak begitu dikenal dan kurang maksimal dilakukan masyarakat. Namun di masa pandemi ini, istilah ini mulai semakin menggema di masyarakat. Bahkan setiap individu telah melakukan perilaku hidup bersih dan sehat ini di dalam lingkungan keluarga dan masyarakat. Perilaku hidup bersih dan sehat adalah upaya untuk memberikan pengalaman belajar atau menciptakan suatu kondisi bagi perorangan, keluarga, kelompok dan masyarakat dengan membuka jalur komunikasi, memberikan informasi dan melakukan edukasi untuk meningkatkan pengetahuan, sikap dan perilaku guna membantu masyarakat mengenali dan mengatasi masalahnya sendiri sehingga masyarakat sadar, mau dan mampu mempraktekkan PUBS melalui pendekatan pimpinan (Mardhiati, 2013).

Perilaku hidup bersih dan sehat adalah semua perilaku kesehatan yang dilakukan karena kesadaran peribadi sehingga keluarga dan seluruh anggotanya mampu menolong diri sendiri pada bidang kesehatan serta memiliki peran aktif dalam aktivitas masyarakat. Tujuan utama dari gerakan perilaku hidup bersih dan sehata dalah meningkatkan kualitas kesehatan melalui proses menyadarkan pemahaman yang menjadi awal dari kontibusi individu-individu dalam menjalani perilaku kehidupan sehari-hari yang bersih dan sehat. Sehingga manfaat perilaku hidup bersih dan sehat yang paling utama/secara khusus adalah terciptanya masyarakat yang sadar kesehatan dan memiliki bekal pengetahuan dan kesadaran untuk menjalani perilaku hidup yang menjaga kebersihan dan memenuhi standar kesehatan.Ada 5 (lima) tatanan perilaku hidup bersih dan sehat yang dapat menjadi simpul untuk memulai proses menyadarkan pengetahuan tentang perilaku hidup bersih dan sehat, yaitu: (1). Perilaku hidup bersih dan sehat di rumah tangga, (2). Perilaku hidup bersih dan sehat di sekolah, (3). Perilaku Hidup Bersih dan Sehat di Tempat Kerja, (4). Perilaku hidup bersih dan sehat di sarana kesehatan, (5). Perilaku hidup bersih dan sehat di tempat umum (Moerad et al., 2019)

Membentuk perilaku sehat anak dimulai sejak usia dini. Hal ini dikarenakan usia dini merupakan masa Golden Age (Usia keemasan). Masa Golden Age merupakan masa di mana tahap perkembangan otak pada anak usia dini menempati posisi yang paling vital 
yakni mencapai $80 \%$ perkembangan otak. Pada masa usia dini kemampuan memori otak mencapai tingkat maksimal. Stimulasi perkembangan dilakukan keluarga setiap saat dalam suasana menyenangkan, dan pemantauan (deteksi) perkembangan dilakukan keluarga setiap bulan sesuai umur anak, mengacu informasi pada Buku KIA. Tools pemantauan perkembangan dalam Buku KIA tersedia dalam rentang umur 0-3 bulan, 3-6 bulan, 6-12 bulan, 1-2 tahun, 2-3 tahun, 3-5 tahun dan 5-6 tahun (Kemenkes, 2020).

\section{METODOLOGI}

Penelitian ini dilakukan dengan metode penelitian survey deskriptif kuantitatif, metode ini hampir sama dengan metode deskriptif. Perbedaannya, metode survei penjelas, menekankan pada pencarian hubungan sebab akibat atau kausal antara variabel yang diteliti. Metode survey merupakan penelitian yang sumber data dan informasi utamanya diperoleh dari responden sebagai sampel penelitian dengan menggunakan angket sebagai instrumen pengumpulan data. Responden pada penelitian ini adalah orang tua yang memiliki anak usia 4-6 yahun yang sedang menempuh jenjang Pendidikan Anak Usia Dini di Kendari yaitu KB Sultan Qaimuddin Kendari dan KB Nurul Maghfirah Kendari. Responden pada penelitian ini sebanyak 51 responden dan dilakukan mulai bulau MaretMei tahun 2020. Teknik pengumpulan data menggunakan wawancara dan angket. Analisis data dalam penelitian ini ialah mengatur, mengurutkan, mengelompokkan, memberikan kode, dan mengategorikannya. Adanya kegiatan mengelompokkan, membuat suatu urutan, memanipulasi serta menyingkatkan data adalah supaya data mudah untuk dibaca. Analisis yang digunakan sudah jelas yaitu diarahkan untuk menguji hipotesis yang telah dirumuskan. Hipotesis dalam survey ini adalah pola asuh orang tua dalam menerapkan perilaku hidup bersih dan sehat anak usia dini dalam kategori sangat baik.

Penelitian ini dapat digambar melalui bagan berikut ini:

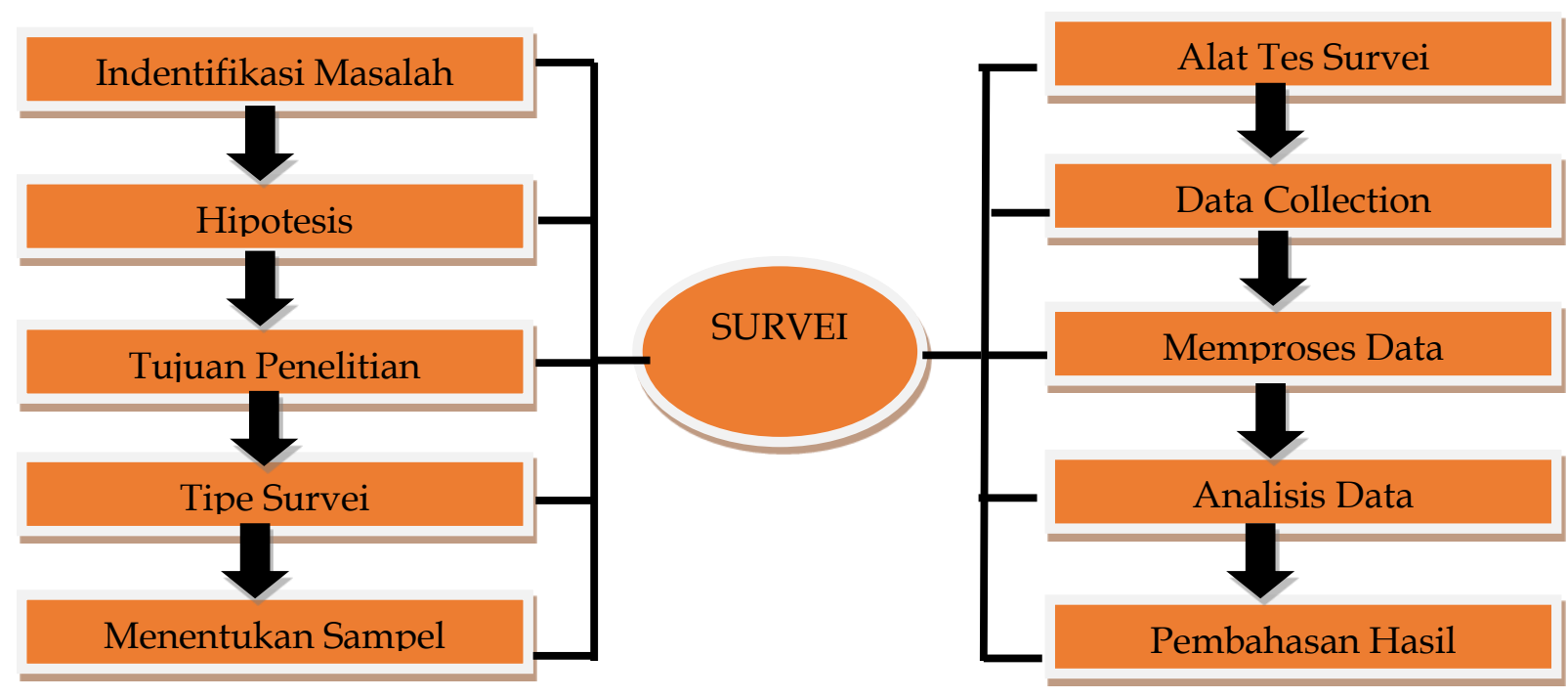

Gambar Desain Penelitian

\section{HASIL DAN PEMBAHASAN}

Kondisi Pandemi Covid-19 pada akhirnya membuat perilaku hidup bersih dan sehat menjadi rutinitas bahkan keharusan. Bagaimana tidak, ancaman penyebaran Covid-19 yang sangat mudah meluas. Virus ini mampu bertahan hidup di berbagai jenis benda dalam beberapa jam, bahkan ada yang sampai beberapa hari. Maka dari itu, masyarakat terus dihimbau untuk melaksanakan perilaku hidup bersih dan sehat ini. Yang paling sering dilakukan misalnya mencuci tangan setiap 1-2 jam, dan mencuci tangan dengan cara yang benar. Selain itu, melakukan aktivitas fisik seperti berolahraga secara rutin di dalam rumah 
bisa dilakukan. Serta, mengkomsumsi makanan sehat dan seimbang yang mengandung berbgai vitamin untuk daya tahan tubuh. Dari temuan di lapangan terlihat bahwa orang tua memiliki kesadaran yang tinggi terhadap pentingnya perilaku hidup bersih dan sehat di lingkungan keluarga untuk diterapkan pada anak. Seluruh responden menjawab sangat penting penerapan perilaku hidup bersih dan sehat, sesuai diagram di bawah ini:

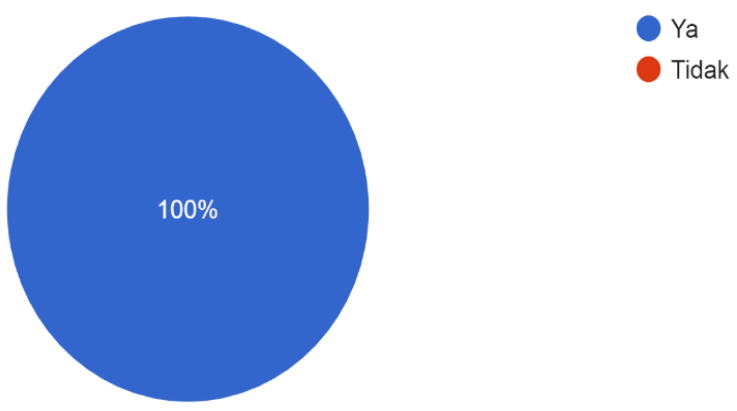

Diagram 1. Pentingnya perilaku hidup bersih dan sehat.

Lingkungan keluarga terbentuk rutinitas dan kebiasaan yang akan menjadi karakter yang baik dalam peningkatan derajat kesehatan. Budaya sehat akan terbentuk pada setiap individu di dalam keluarga. Orang tua setidaknya memberikan contoh nyata dalam melaksanakan perilaku ini kepada putra-putrinya. Sehingga anak-anak akan meniru dan ikut melaksanakan perilaku hidup bersih dan sehat ini dengan semangat, didampingi para orang tua yang peduli dengan anaknya. Walaupun selama ini masih ada orang tua yang belum pernah mengetahui program perilaku hidup bersih dan sehat ini. Hal ini dapat terlihat dari digram di bawah ini:

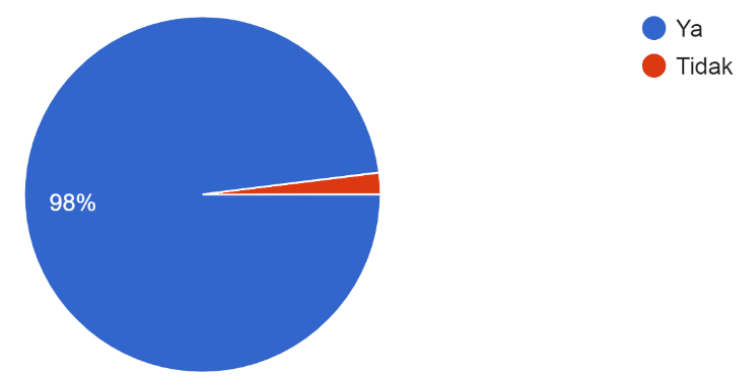

Diagram 2. Pengetahuan Orang Tua Terhadap Perilaku Hidup Bersih dan Sehat.

Dari diagram di atas terlihat sebanyak $98 \%$ atau 50 responden sudah mengetahui program perilaku hidup bersih dan sehat sedangkan sebanyak $2 \%$ atau 1 responden belum mengetahui program Perilaku Hidup Bersih dan Sehat. Dengan pengetahuan orang tua tentang program Perilaku Hidup Bersih dan Sehat ini setidaknya bisa membiasakan anak untuk hidup bersih dan sehat sehingga bisa terhindar dari penyebaran virus corona. Walaupun orang tua ada yang sebagian belum pernah mengikuti pelatihan program Perilaku Hidup Bersih dan Sehat. Ini dapat terlihat dari diagram di bawah ini :

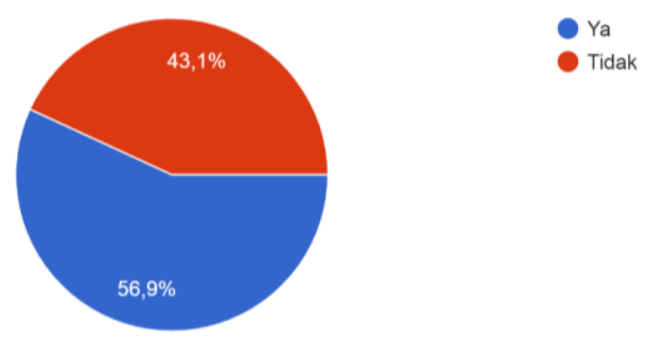

Diagram 3. Orang Tua yang mendapatkan Pelatihan Perilaku Hidup Bersih dan Sehat. 
Dari diagram di atas terlihat bahwa sebanyak $56,9 \%$ atau 29 responden sudah pernah mendapatkan pelatihan sedangkan sebanyak $43,1 \%$ atau 22 responden belum pernah mendapatkan pelatihan program perilaku hidup bersih dan sehat. Namun dengan adanya virus corona ini orang tua mencari sendiri bagaimana cara penerapan perilaku hidup bersih dan sehat melalui media online seperti youtube, artikel berita, dan mengakses berita dari gugus tugas covid 19. Sebagaimana yang dituturkan oleh orang tua bahwa mereka mengakses youtube (Wawancara, AS tanggal 9 Mei 2020), membaca berita secara online tentang penanganan virus corona di lingkungan keluarga (wawancara, M tanggal 9 Mei 2020) dan mengakses berita-berita yang ada pada website gugus tugas penanganan virus corona https://www.covid19.go.id/ (wawancara, S tanggal 9 Mei 2019). Bentuk-bentuk perilaku hidup bersih dan sehat yang diterapkan oleh orang tua kepada anak selama pandemik ini sesuai dengan anjuran pemerintah dengan menerapkan selalu jaga jarak, mencuci tangan dengan sabun, bila keluar rumah selalu menggunakan maskes dan menjaga kebersihan lingkungan rumah. Hal ini seperti diungkapkan oleh orang tua bahwa: Cuci tangan 20 detik menjaga kebersihan rumah mencuci sayur dan buah jika dari luar langsung mandi dan merendam baju yg telah digunakan (wawancara, M tanggal 9 Mei 2020), Selalu cuci tangan dengan sabun di bawa air mengalir selama minimal 20 detik. Tidak memegang wajah dengan tangan kotor. Jika ada keperluan penting keluar rumah selalu menggunakan masker (wawancara, SGP tanggal 9 Mei 2020), jaga kebersihan di rumah dan lingkungan, selalu cuci tangan sehabis beraktivitas. Makan yang memenuhi empat sehat lima sempurna, mandi $2 x$ sehari, tidur yg cukup dan tambahan minum vitamin setiap hari (wawancara VR tanggal 9 Mei 2020), dan rajin cuci tangan, keluar rumah wajib pakai masker, bersin tutup mulut dengan masker/siku dalam, saat ini tidak boleh salaman, mandi $2 x$ sehari, perbanyak makan sayur, tidak boleh berkerumun/jaga jarak dengen orang dari luar rumah (wawancara MY tanggal 9 Mei 2020). Menurut Roger, untuk membentuk sebuah perilaku yang positif, maka harus didasari oleh pengetahuan(Zulfa Husni Khumayra; Madya Sulisno, 2012). Hal ini berhubungan dengan faktor yang mempengaruhi pengetahuan yaitu informasi. Informasi akan memberikan pengaruh pada pengetahuan seseorang. Jika pada individu tidak diberikan sebuah informasi yang benar, maka akan dipersepsikan atau terbentuk sikap yang tidak baik pula sehingga membentuk sebuah perilaku yang kurang baik atau negatif.

Jika dilihat dari data dan hasil wawancara terlihat bahwa tingkat pemahaman orang tua terhadap perilaku hidup bersih dan sehat di tengah pandemi ini sangat baik dalam menjaga kesehatan diri dan anaknya. Jika dilihat dari tingkat pendidikan orang tua yang menjadi responden rata-rata pendidikan mereka adalah sarjana (S1), hal ini dapat dilihat dari distribusi diagram dibawa ini:

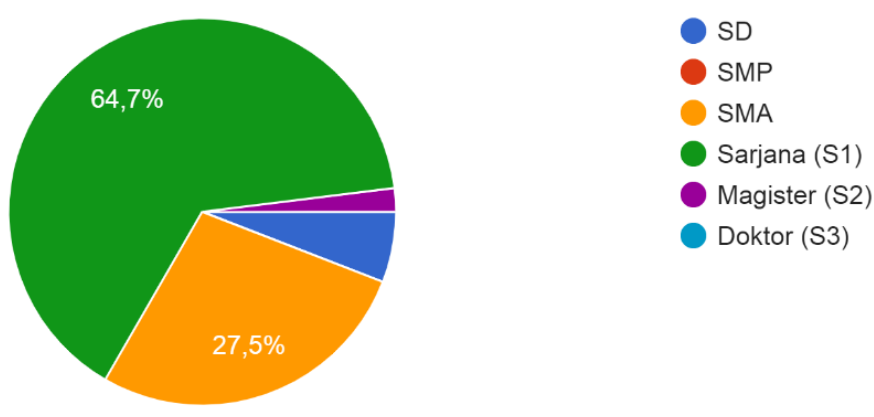

Diagram 4. Pendidikan Orang Tua.

Dari diagram di atas terlihat bahwa sebanyak $64,7 \%$ atau 33 responden memiliki pendidikan sarjana (S1), sebanyak $27,5 \%$ atau 14 responden memiliki pendidikan Sekolah Menengah Atas (SMA), sebanyak 5,9\% atau 3 responden memiliki pendidikan Sekolah Dasar, dan sebanyak 2\% atau 1 responden memiliki pendidikan Magister (S2). Tingkat 
pendidikan orang tua ini akan mempengaruhi pemahaman orang tua terhadap pentingnya perilaku hidup bersih dan sehat ditengah pendemi corona ini. Hal ini sesuai dengan penelitian terdahulu yang menemukan bahwa hasil rekapitulasi data dari Dinas Kesehatan Kabupaten Sragen diperoleh data skor PHBS terendah adalah wilayah kerja Puskesmas Tanon II Desa Karangasem. Desa Karangasem termasuk sehat pratama 17,50 \%. Perilaku yang didasari oleh pengetahuan akan lebih langeng dari pada perilaku yang tidak didasari oleh pengetahuan, sebab perilaku ini terjadi akibat adanya paksaan atau aturan yang mengharuskan untuk berbuat. Salah satu wujud dari perilaku adalah pengetahuan. Pengetahuan seseorang dipengaruhi oleh beberapa faktor: pendidikan, pekerjaan dan Umur (Wahyuni Erna Irawati, 2011).

Edukasi pengetahuan anak terhadap virus corona ini sangat diperlukan sehingga anak tidak merasa bosan tinggal di rumah. Orang tua harus mampu membuat suasana di rumah lebih menyenangkan sehingga anak bisa betah tinggal di dalam rumah. Pemberian pemahaman terkait virus corona juga diperlukan sehingga anak tidak bertanya-tanya kenapa saya tidak boleh bermain dengan teman-teman, tidak boleh ke sekolah dan lain-lain pertanyaan yang akan timbul ketika orang tua tidak mampu memberikan pemahaman kepada anak. Pemberian pemahaman pun harus melihat usia perkembangan anak yang masih duduk di bangku PAUD yang harus berbeda dengan pemberian pemahaman kepada orang yang dewasa. Berdasarkan hasil wawancara dengan orang tua terlihat bahwa orang tua memberikan penjelasan terkait dengan virus corona menyesuiakan bahasa sesuai perkembangan anaknya, seperti yang diungkapkan bahwa memberikan pemahaman dengan menggunakan gambar yang mudah dimengerti dan memberikan contoh hidup sehat dan bersih (wawancara, $\mathrm{N}$ tanggal 9 Mei 2020), menjelaskan sambil memperlihatkan penjelasan dari televisi dan youtube (wawancara, R tanggal 9 Mei 2020), virus Corona bisa dimatikan dengan mencuci tangan pakai sabun minimal 20 detik, dapat dihindari dengan menggunakan masker, jaga jarak jika keluar rumah dan sering cuci tangan (wawancara, D tanggal 9 Mei 2020). Dari hasil penelitian diperlihatkan bahwa memang perlu ada satu moment seperti sekarang ketika setiap anggota keluarga memiliki banyak waktu di rumah sehingga rumah tidak sekadar tempat singgah. Orang tua beraktivitas bersama dengan anak, mulai dari berjemur bersama, beribadah bersama, bermain bersama, sampai mendampingi anak belajar yang biasanya diserahkan pada guru di sekolah. Kemampuan memahami peran masing-masing antaranggota keluarga adalah hal yang penting juga dalam beraktivitas bersama selama masa social distancing dan physical distancing karena qualiy time itu bukan bicara kuantitas, tetapi kualitas dari kebersamaan juga (Andalusia Neneng Permatasari, Dinar Nur Inten, Wiliani, 2021)

Pemberian pemahaman kepada anak harus disertai memberikan contoh terhadap perilaku hidup bersih dan sehat. Dari hasil angket terlihat bahwa sebanyak 100\% responden memberikan contoh yang baik terhadap anak, seperti jika keluar rumah harus menggunakan masker, jaga jarak, cuci tangan minimal 20 detik, makan-makan yang bergizi, berjemur, dan langsung mandi dan mengganti baju jika keluar rumah. Dengan pemberian contoh yang baik dari orang tua maka anak akan meniru yang dilakukan oleh orang tuanya. Sehingga tidak hanya pemberian pemahaman yang dilakukan oleh orang tua tapi sudah langsung memberikan contoh perilaku hidup bersih dan sehat. Adiwiryono menyatakan bahwa peran orang tua merupakan faktor eksternal terhadap praktik perilaku hidup bersih dan sehat di sekolah.Bila orang tua memiliki pengetahuan yang baik dan waktu yang cukup untuk memberikan contoh tentang perilaku hidup bersih dan sehat dan memberikan informasi tentang manfaat, tujuan dan arti penting perilaku hidup bersih dan sehat bagi anak di lingkungan sekolah maka praktik anak terhadap perilaku hidup bersih dan sehat menjadi lebih baik(Berliana, 2016).

Pemberian pemahaman dan contoh yang baik dari orang tua diharapkan dapat menimbulkan kemandirian anak usia dini terhadap perilaku hidup bersih dan sehat ditengah masa pandemi ini. Kemandirian akan membawa anak untuk terbiasa dalam 
menerapkan perilaku hidup bersih dan sehat dalam kehidupan sehari-hari. Berdasarkan hasil penelitian menyimpulkan bahwa membiasakan pola hidup sehat pada anak pada masa pandemi covid-19 dapat dilakukan dengan cara mengingatkan anak untuk memakanmakanan yang bergizi seperti sayur dan buah, berolahraga teratur dan istirahat yang cukup serta berjemur setiap pagi sekitar 10-15 menit. Selain mengingatkan guru juga memberikan kegiatan sederhana kepada anak yang disampaikan melalui rekaman video atau rekaman suara kepada anak (Hana Ika Safitri; Harun, 2021). Dari hasil penelitian ini ditemukan bahwa tingkat penerapan perilaku hidup bersih dan sehat anak usia dini dalam kategori sangat baik, sebagaimana tabel di bawah ini:

Tabel 1. Penerapan perilaku hidup bersih dan sehat anak usia dini.

\begin{tabular}{|c|c|c|c|}
\hline \multirow{2}{*}{ No } & \multirow{2}{*}{ Perilaku Hidup Bersih dan Sehat } & \multicolumn{2}{|c|}{ Jawaban } \\
\hline & & Ya (\%) & Tidak (\%) \\
\hline 1 & Anak membuang sampah pada tempatnya & $\begin{array}{l}100 \% \text { atau } 51 \\
\text { responden }\end{array}$ & $0 \%$ \\
\hline 2 & Anak merapikan sendiri permainannya & $\begin{array}{l}92,2 \% \text { atau } 47 \\
\text { responden }\end{array}$ & $\begin{array}{l}7,8 \% \text { atau } 4 \\
\text { responden }\end{array}$ \\
\hline 3 & $\begin{array}{l}\text { Anak mencuci tangan dengan sabun setelah } \\
\text { bermain }\end{array}$ & $\begin{array}{l}98 \% \text { atau } 50 \\
\text { responden }\end{array}$ & $2 \%$ atau 1 responden \\
\hline 4 & Anak membantu membersihkan rumah & $\begin{array}{l}80,4 \% \text { atau } 41 \\
\text { responden }\end{array}$ & $\begin{array}{l}19,6 \% \text { atau } 10 \\
\text { responden }\end{array}$ \\
\hline 5 & $\begin{array}{l}\text { Anak merapikan sendal dan sepatu pada } \\
\text { tempatnya }\end{array}$ & $\begin{array}{l}88,2 \% \text { atau } 45 \\
\text { responden }\end{array}$ & $\begin{array}{l}11,8 \% \text { atau } 6 \\
\text { responden }\end{array}$ \\
\hline 6 & $\begin{array}{l}\text { Anak buang air besar dan buang air kecil } \\
\text { pada tempatnya }\end{array}$ & $\begin{array}{l}100 \% \text { atau } 51 \\
\text { responden }\end{array}$ & $0 \%$ \\
\hline 7 & $\begin{array}{l}\text { Anak jika bersin menutup mulutnya dengan } \\
\text { telapak tangan }\end{array}$ & $\begin{array}{c}100 \% \text { atau } 51 \\
\text { responden }\end{array}$ & $0 \%$ \\
\hline 8 & Anak mandi 2 kali dalam sehari & $\begin{array}{l}96 \% \text { atau } 48 \\
\text { responden }\end{array}$ & $4 \%$ atau 3 responden \\
\hline 9 & $\begin{array}{l}\text { Anak cuci tangan dengan sabun sebelum } \\
\text { makan }\end{array}$ & $\begin{array}{c}100 \% \text { atau } 51 \\
\text { Responden }\end{array}$ & $0 \%$ \\
\hline 10 & Anak terbiasa sarapan pagi & $\begin{array}{l}90,2 \% \text { atau } 46 \\
\text { responden }\end{array}$ & $\begin{array}{l}9,8 \% \text { atau } 5 \\
\text { responden }\end{array}$ \\
\hline 11 & Anak makan 3 kali dalam sehari & $\begin{array}{l}92,2 \% \text { atau } 47 \\
\text { responden }\end{array}$ & $\begin{array}{l}7,8 \% \text { atau } 4 \\
\text { responden }\end{array}$ \\
\hline 12 & Anak minum susu tiap hari & $\begin{array}{l}84,3 \% \text { atau } 43 \\
\text { responden }\end{array}$ & $\begin{array}{c}15,7 \% \text { atau } 8 \\
\text { responden }\end{array}$ \\
\hline 13 & Anak makan makanan bergizi & $\begin{array}{c}100 \% \text { atau } 51 \\
\text { responden }\end{array}$ & $0 \%$ \\
\hline 14 & $\begin{array}{l}\text { Anak jika keluar rumah menggunakan } \\
\text { masker }\end{array}$ & $\begin{array}{l}98 \% \text { atau } 50 \\
\text { responden }\end{array}$ & $2 \%$ atau 1 responden \\
\hline 15 & $\begin{array}{l}\text { Anak jika sudah kembali ke rumah langsung } \\
\text { mandi dan mengganti baju }\end{array}$ & $\begin{array}{c}100 \% \text { atau } 51 \\
\text { responden }\end{array}$ & $0 \%$ \\
\hline 16 & Anak suka berjemur di pagi hari & $\begin{array}{c}100 \% \text { atau } 51 \\
\text { responden }\end{array}$ & $0 \%$ \\
\hline
\end{tabular}

Dari data tabel terlihat bahwa sebanyak $100 \%$ atau 51 responden anak membuang sampah pada tempatnya. Sebanyak $92,2 \%$ atau 47 responden anak merapikan sendiri permainannya dan sebanyak $7,8 \%$ atau 4 responden anak yang tidak merapikan sendiri permainannya. Sebanyak $98 \%$ atau 50 responden anak mencuci tangan dengan sabun setelah bermain dan $2 \%$ atau 1 responden anak yang tidak mencuci tangan dengan sabun setelah bermain. Sebanyak $80,4 \%$ atau 41 responden anak membantu membersihkan rumah dan $19,6 \%$ atau 10 responden anak yang tidak membantu membersihkan rumah. Sebanyak $88,2 \%$ atau 45 responden anak merapikan sendal dan sepatu pada tempatnya dan sebanyak 
$11,8 \%$ atau 6 responden anak yang tidak merapikan sendal dan sepatu pada tempatnya. Sebanyak $100 \%$ atau 51 responden anak buang air besar dan buang air kecil pada tempatnya. Sebanyak 100\% atau 51 responden anak jika bersih menutup mulutnya dengan telapak tangan. Sebanyak $96 \%$ atau 48 responden anak mandi 2 kali dalam sehari dan sebanyak $4 \%$ atau 3 responden anak tidak mandi 2 kali dalam sehari. Sebanyak $100 \%$ atau 51 responden anak cuci tangan dengan sabun sebelum makan. Sebanyak 90,2\% atau 46 responden anak terbiasa sarapan pagi dan sebanyak 9,8\% atau 5 responden anak tidak terbiasa sarapan pagi. Sebanyak $92,2 \%$ atau 47 responden anak makan 3 kali dalam sehari dan sebanyak $7,8 \%$ atau 4 responden anak tidak makan 3 kali dalam sehari. Sebanyak $84,3 \%$ atau 43 responden anak minum susu tiap hari dan sebanyak $15,7 \%$ atau 8 responden anak tidak minum susu tiap hari. Sebanyak $100 \%$ atau 51 responden anak makan makanan bergizi. Sebanyak $98 \%$ atau 50 responden anak jika keluar rumah menggunakan masker dan sebanyak $2 \%$ atau 1 responden anak jika keluar rumah tidak menggunakan masker. Sebanyak $100 \%$ atau 51 responden anak jika sudah kembali kerumah langsung mandi dan mengganti baju dan sebanyak $100 \%$ atau 51 responden anak suka berjemur di pagi hari. Data data ini terlihat orang tua dan anak sangat memperhatikan kesehatan di tengah pandemi covid 19.

Perilaku hidup bersih dan sehat merupakan hal penting bagi kelangsungan hidup seluruh anggota keluarga. Alasannya, tak lain untuk dapat hidup sehat dan sejahtera saat ini dan investasi kesehatan masa depan. Manfaat mengembangkan perilaku sehat sejak dini adalah anak akan memiliki pola hidup sehat di kemudian hari. Artinya anak usia dini yang terbiasa dengan perilaku hidup sehat tidak mudah hilang pada tahapan perkembangan selanjutnya. Selain itu anak usia dini telah memiliki pola hidup sehat, maka mereka akan terbebas dari serangan berbagai macam penyakit yang sering terjadi pada anak usia dini, seperti batuk/ pilek, flek atau TBC, diare, demam, campak. infeksi telinga, dan penyakit kulit terlebih di masa pandemic Covid-19 yang salah satu cara memutus penyebarannya dengan penerapan pola hidup sehat yaitu rajin mencuci tangan dengan menggunakan sabun. Indikator Perilaku Hidup Bersih dan Sehat salah satunya mencuci tangan dengan air mengalir dan sabun yang merupakan sekumpulan perilaku yang dilakukan karena kesadaran dari hasil pembelajaran, yang membuat individu atau keluarga dapat menjaga dan memelihara kesehatan serta berperan aktif untuk mewujudkan masyarakat sehat (Kemenkes RI, 2014).

Kebiasaan dalam cuci tangan menggunakan air saja tidak dapat melindungi setiap individu dari bakteri dan virus yang terdapat di tangan. Terlebih jika mencuci tangan tidak di bawah air mengalir. Apalagi kebiasaan menggunakan dan berbagi wadah cuci tangan hal itu sama saja saling berbagi kuman dan tetap membiarkan kuman menempel pada tangan. Kebiasaan itu harus ditinggalkan dan dirubah menjadi yang lebih baik dengan standar prosedur melakukan cuci tangan menggunakan sabun (Kemenkes RI, 2014). Cara cuci tangan pakai sabun yang benar adalah menggosok telapak tangan secara bersamaan, menggosok punggung kedua tangan, jalinkan kedua telapak tangan lalu digosok-gosokkan, tautkan jari-jari antara kedua telapak tangan secara berlawanan, gosok ibu jari secara memutar dilanjutkan dengan daerah antara jari telunjuk dan ibu jari secara bergantian, gosok kedua pergelangan tangan dengan arah memutar, bilas dengan air dan keringkan. Hal terpenting dalam CTPS bukan berapa lama waktu mencuci tangan, tetapi cara mencuci tangannya (Kemenkes RI, 2014).

Menggunakan sabun saat mencuci tangan diketahui sebagai salah satu upaya pencegahan penyakit dan penularan penyakit. Hal ini dilakukan karena tangan merupakan agen yang membawa kuman dan menyebabkan patogen berpindah dari satu orang ke orang lain, baik dengan kontak tidak langsung maupun kontak langsung (menggunakan permukaan lain seperti handuk dan gelas) (Kemenkes RI, 2013). Membentuk pola hidup sehat lebih mudah daripada mengubah perilaku hidup sehat. Sekali lagi tugas membentuk perilaku sehat pada anak usia dini bukan menjadi tugas orang tua semata, melainkan 
juga pihak sekolah. Antara sekolah dan orang tua harus bekerja sama supaya anak usia dini memperoleh pendidikan tentang pola hidup sehat, sehingga dapat menjadi jaminan untuk hari depan tubuh yang sehat. Tentu saja, dibandingkan dengan sekolah, maka orang tua mempunyai peran yang lebih besar dalam membentuk perilaku sehat ini. Karena orang tua adalah pendidik yang pertama dan utama (Syahreni E, 2011).

Menurut Soekidjo Notoatmojo (2010) faktor-faktor yang berpengaruh terhadap perilaku hidup sehat antara lain: (a). Faktor makanan dan minuman terdiri dari kebiasaan makan pagi (sarapan), pemilihan jenis asupan makanan, jumlah makanan dan minuman serta kebersihan makanan. (b). Faktor perilaku terhadap kebersihan diri sendiri terdiri dari mandi, membersihkan mulut dan gigi, tangan dan kaki serta kebersihan pakaian. (c). Faktor perilaku terhadap kebersihan lingkungan yang terdiri dari kebersihan kamar, rumah, lingkungan sekolah. (d). Faktor perilaku terhadap sakit dan penyakit terdiri dari pemeliharaan kesehatan, pencegahan terhadap penyakit, rencana pengobatan serta pemulihan kesehatan. (3). Faktor keseimbangan antara kegiatan istirahat dan olah raga terdiri dari banyaknya waktu istirahat, aktivitas di rumah atau diluar rumah dan olah raga teratur (Notoadmojo S, 2010).

Menurut Notoatmojo beberapa hal yang perlu diajarkan pada anak untuk mengembangkan perilaku sehat, yaitu menjaga kebersihan diri maupun kebersihan lingkungan dan menjauhkan hal-hal yang berbahaya untuk kesehatan. Kebersihan lingkungan adalah kebersihan tempat tinggal, tempat kerja atau bermain, dan sarana umum(Notoadmodjo S, 2010). Anak dapat diajarkan tentang kebersihan lingkungan ini sejak dini. Kegiatan paling sederhana yang dapat dilakukan anak usia dini adalah meletakkan alas kaki pada tempatnya; menggunakan alas kaki jika hendak keluar rumah; membuang sampah pada tempatnya; meletakkan peralatan makan minum yang kotor pada tempatnya; membersihkan mainan; menutup mulut pada saat batuk dan bersin; menjauhi asap rokok, asap pembakaran sampah, asap kendaraan bermotor; serta buang air besar (BAB) dan buang air kecil (BAK) di toilet. Selain itu orang tua dapat melibatkan anak usia dini dalam kegiatan-kegiatan terkait dengan pemeliharaan kebersihan lingkungan seperti membereskan mainan, menyapu rumah, mengepel rumah, menyapu halaman, dan lain-lain.

Kebersihan diri adalah kebersihan anggota tubuh dan pakaian. Adapun kegiatan untuk menjaga kebersihan diri akan diuraikan sebagai berikut, mandi dilakukan minimal dua kali dalam sehari yaitu pada pagi dan sore. Anak dimandikan dengan menggunakan sabun mandi dan air bersih. Keramas, mencuci rambut dengan menggunakan sampho khusus untuk anak secara teratur dilakukan minimal dua hari sekali. Selanjutnya rambut dirapikan dengan menggunakan sisir yang tepat supaya minyak alami yang terdapat pada rambut dapat menyebar ke seluruh bagian rambut. Sehingga rambut dapat terangsang pertumbuhannya serta melancarkan peredaran darah pada rambut dan kulit kepala.

Membersihkan telinga bagian luar dan bagian belakang telinga setiap hari dengan menggunakan waslap atau handuk pada saat mandi. Menghindari membersihkan lubang telinga bagian dalam karena dapat membahayakan. Karena prinsipnya kotoran telinga dapat keluar dengan sendirinya ketika kita mengunyah makanan. Perawatan gigi, dengan menggosok gigi untuk membersihkan dari sisa-sisa makanan yang menempel pada gigi, karena jika tidak dibersihkan dapat menyebabkan gigi rusak sehingga kemampuan anak untuk menguyah makanan akan terganggu. Agar anak terbiasa merawat giginya, gosoklah gigi anak, segera setelah gigi pertamanya tumbuh dan lakukan gosok gigi secara teratur dua kali sehari, pada pagi dan malam sebelum tidur. Selain itu supaya gigi anak sehat, jauhkan anak usia dini dari makanan atau minuman yang terlalu manis dan bersoda, seperti permen, cokelat, dan soft drink (minuman ringan mengandung soda). Kebutuhan gizi, memberikan makanan yang benar pada anak harus dilihat dari banyak aspek, seperti ekonomi, sosial, budaya, agama, disamping aspek medik dari anak itu sendiri. Makanan pada anak usia dini harus serasi, selaras dan seimbang. Serasi artinya sesuai 
dengan tingkat tumbuh kembang anak. Selaras adalah sesuai dengan kondisi ekonomi, sosial budaya serta agama dari keluarga. Sedangkan seimbang artinya nilai gizinya harus sesuai dengan kebutuhan berdasarkan usia dan jenis bahan makanan seperti karbohidrat, protein dan lemak (Soetjiningsih, 2002).

Ini merupakan momentum yang baik dalam menumbuhkan karakter anak dalam menjaga kesehatan diri dan lingkungannya. Walaupun kita dalam kondisi yang sulit, namun di setiap kondisi sesulit apapun, pasti ada hal positif yang bisa dioptimalkan. Anak harus tetap dibimbing dan diberikan contoh langsung dalam melakukan perilaku hidup bersih dan sehat ini, agar menjadi semakin semangat. Kompak merupakan kunci sukses dari perilaku hidup bersih dan sehat ini, bahkan kunci dari upaya memutus pandemi Covid-19 ini. Orang tua semestinya tetap kompak dan memotivasi putra-putrinya untuk melakukan perilaku hidup bersih dan sehat ini.Walaupun nantinya pandemi ini telah berakhir, setidaknya ada hal positif yang orang tua pelajari, yaitu tumbuhnya karakter kuat dalam mengupayakan diri dan lingkungan mereka tetap sehat. Semoga karakter positif setiap anak ini nantinya memfosil dan menjadi budaya di masyarakat ketika mereka dewasa nanti. Semoga karakter ini tidak hanya tumbuh di saat seperti ini, namun diteruskan sampai nanti di setiap waktu, kondisi, bagian atau tatanan kehidupan anak.

\section{SIMPULAN}

Perilaku hidup bersih dan sehat anak usia dini di lingkungan keluarga sudah berjalan sangat baik di tengah pademi covid 19. Hasil penelitian bahwa penerapan perilaku hidup bersih dan sehat anak usia dini dalam kategori sangat baik, dari data Sebanyak 100\% atau 51 respondenanak cuci tangan dengan sabun sebelum makan. Sebanyak $98 \%$ atau 50 responden anak jika keluar rumah menggunakan masker dan sebanyak $2 \%$ atau 1 responden anak jika keluar rumah tidak menggunakan masker. Sebanyak 100\% atau 51 responden anak jika sudah kembali kerumah langsung mandi dan mengganti baju dan sebanyak $100 \%$ atau 51 responden anak suka berjemur di pagi hari.

\section{UCAPAN TERIMA KASIH}

Terima kasih penulis ucapkan kepada kepala sekolah dan guru KB Sultan Qaimuddin Kendari dan KB Nurul Maghfirah Kendari dan Orang tua dan semua pihak yang telah membantu pelaksanaan penelitian dan penulisan artikel ini. Tidak lupa ucapan terima kasih kepada editor dan reviewer Journal Obsesi yang sudah memberikan kesempatan sehingga jurnal bisa untuk diterbitkan.

\section{DAFTAR PUSTAKA}

Andalusia Neneng Permatasari, Dinar Nur Inten, Wiliani, K. N. W. (2021). Keintiman Komunikasi Keluarga saat Social Distancing Abstrak. Jurnal Obsesi : Jurnal Pendidikan Anak Usia Dini, 5(1), 346-359. https:/ / doi.org/10.31004/ obsesi.v5i1.577

Apriliana Kuntoro Astuti. (2016). Pelaksanaan Perilaku Sehat Pada Anak Usia Dini Di PAUD Purwomukti Desa Batur Kecamatan Getasan. Scholaria: Jurnal Pendidikan Dan Kebudayaan, 6(3), 264. https:// doi.org/10.24246/j.scholaria.2016.v6.i3.p264-272

Berliana, N. (2016). Hubungan Peran Orangtua, Pengaruh Teman Sebaya Dengan Perilaku Hidup Bersih Dan Sehat. Jurnal Endurance, 1(2), 75-80. https:/ / doi.org/10.22216/jen.v1i2.984

Erik Sulistiana, R. S. I. (2013). Studi Tentang Pola Asuh Orang Tua Terhadap Perilaku Hidup Bersih Dan Sehat Anak Usia 3 - 4 Tahun. Embrio, Jurnal Kebidanan, 2(1), 36-39. https:/ / doi.org/10.1017/CBO9781107415324.004

Fitroh, S. F., \& Oktavianingsih, E. (2020). Peran Parenting dalam Meningkatkan Literasi Kesehatan Ibu terhadap Stunting di Bangkalan Madura. Jurnal Obsesi: Jurnal Pendidikan Anak Usia Dini, 4(2), 610-619. https:/ / doi.org/10.31004/obsesi.v4i2.415

Giantara, F., Yanti, N., Handayani, S., \& Anis, Y. (2020). Pola Pendidikan keluarga Saat 
Bencana Kabut Asap di Kota Pekanbaru. Jurnal Obsesi : Jurnal Pendidikan Anak Usia Dini, 4(2), 778. https:// doi.org/10.31004/obsesi.v4i2.446

Hana Ika Safitri; Harun. (2021). Membiasakan Pola Hidup Sehat dan Bersih pada Anak Usia Dini Selama Pandemi Covid-19. Jurnal Obsesi : Jurnal Pendidikan Anak Usia Dini, 5(1), 385-394. https://doi.org/10.31004/obsesi.v5i1.542

Heny Wulandari. (2014). Pelaksanaan Pendidikan Kesehatan, Perilaku Hidup Bersih dan Sehat pada Anak Usia Dini. Shautut Tarbiyah, 30(1), 69-85. https://doi.org/http://dx.doi.org/10.31332/str.v20i1.35

Joni. (2015). Hubungan pola asuh orang tua terhadap perkembangan bahasa anak prasekolah. Jurnal Paud Tambusai, 1(6), 42-48. https://doi.org/https://doi.org/10.31004/obsesi.v1i1.54

Kemenkes. (2020). Panduan pelayanan kesehatan balita pada masa tanggap darurat COVID-19. Kemenkes.

Kemenkes RI. (2013). Profil Kesehatan Indonesia. Jakarta: Kemenkes.

Kemenkes RI. (2014). Profil Kesehatan Indonesia. Jakarta: Kemenkes.

La Ode Anhusadar. (2016). Kreativitas Pendidikan Di Lembaga PAUD. Al-Ta'dib, 9(1), 76-93.

Laode Anhusadar. (2020). Persepsi Mahasiswa PIAUD Terhadap Kuliah Online Di Masa Pandemi Covid 19. KINDERGARTEN: Journal of Islamic Early Childhood Education, 3(1), 44-58. https:// doi.org/http://dx.doi.org/10.24014/kjiece.v3i1.9609

Mardhiati, R. (2013). Pesan Kesehatan : Perilaku Hidup Bersih Dan Sehat (PHBS) Anak Usia Dini Dalam Kurikulum Pendidikan Anak Usia Dini, 368.

Moerad, S. K., Susilowati, E., Savitri, E. D., Rai, N. G. M., Windiani, W., Suarmini, N. W., ... Widyastuti, T. (2019). Pendampingan Pelaksanaan Program Perilaku Hidup Bersih dan Sehat (PHBS) Anak Usia Dini - Pos PAUD Terpadu Melati Kelurahan Medokan Ayu - $\quad$ Rungkut Surabaya. Sewagati, https://doi.org/10.12962/j26139960.v3i3.6016

Notoadmodjo S. (2010). Promosi kesehatan teori dan aplikasi. Jakarta: Rineka Cipta.

Notoadmojo S. (2010). Ilmu perilaku kesehatan. Jakarta: Rineka Cipta.

Pratiwi, D. S., Widiastuti, A. A., \& Rahardjo, M. M. (2018). Persepsi Orangtua terhadap Pendidikan Anak Usia Dini Di Lingkungan RW 01 Dukuh krajan Kota Salatiga. Satya Widya, 34(1), 39-49. https:/ / doi.org/10.24246/j.sw.2018.v34.i1.p39-49

Soetjiningsih. (2002). Tumbuh Kembang Anak dan Remaja. Jakarta: Sagung Seto.

Syahreni E. (2011). Mengembangkan Perilaku Sehat Pada Anak Usia 2-4 Tahun. Jakarta: Direktorat Pembinaan Pendidikan Anak Usia Dini Direktorat Jenderal Pendidikan Anak Usia Dini Nonformal dan Informal Kementerian Pendidikan Nasional.

Wahyuni Erna Irawati. (2011). Gambaran Karakteristik Keluarga Tentang Perilaku Hidup Bersih Dan Sehat (Phbs) Pada Tatanan Rumah Tangga Di Desa Karangasem Wilayah Kerja Puskesmas Tanon Ii Sragen. Gaster: Jurnal Kesehatan, 8(2), 25. Retrieved from http://jurnal.stikes-aisyiyah.ac.id/index.php/gaster/article/view/25

Zulfa Husni Khumayra; Madya Sulisno. (2012). Perbedaan Pengetahuan Dan Sikap Perilaku Hidup Bersih. Jurnal Nursing Studies, 1(1), 197-204. 